\title{
The Effect of Role Play for English Students Speaking in Junior High School of SMP Muhammadiyah 11 Sukodadi
}

\author{
Firda Fadhila Aini \\ Universitas Muhammadiyah Gresik \\ fadhilaainiaini@gmail.com \\ Khoirul Anwar \\ Universitas Muhammadiyah Gresik \\ khoirulanwar@umg.ac.id \\ Candra Hadi Asmara \\ Universitas Muhammadiyah Gresik \\ candrafkip@umg.ac.id
}

Received: Agust 10, 2020

Accepted: Agust 17, 2020

Published: August 9, 2020

Doi : http://dx.doi.org/10.30587/jetlal.v4i2.2275

\section{ABSTRACT}

Role play is a method of acting out particular ways of behaving or pretending to be other people who deal with new situations. Role play is very important in teaching speaking because it gives students an opportunity to practice communicating in different social contexts and in different social roles. The purpose of this study is to find out the significant effect on students fluency in speaking skills taught by using Role Play for students in Junior High School. The researcher used an experimental design in which there are two classes; one of the experiment group and the control group that each has 20 students. The data is collected through quantitative methods. The quantitative data is obtained from the result of the pre-test and post-test students speaking skills. Before implement Role Play, students had to take pre-test to identify their speaking ability. One group practice a dialogue in pair use Role Play strategy about greeting, leave taking, thanking and apologizing expressions. Other group was asked to practice a dialogue used drilling strategy. Both groups were tested for their oral production and competence. After the presentation, the post-test was used to find out whether there was a significant effect using Role Play in speaking ability. The implementation of Role Play and Drilling showed that students who are though used Role Play in teaching speaking can improve their speaking skill especially in fluency.

Key words: Role Play, Speaking Skills, Junior High School.

\section{INTRODUCTION}

Nowadays, mastering English is one of factors that can determine peoples successfully in study, career or business. However, there are many of obstacles to be good in English. For people who want to have good competence in communicating using English, they must learn all aspects in English earlier such as pronunciation, grammar, vocabulary, fluency and comprehension. Besides, people must build self-confidence bravery in speaking English. Those can be used as the important aspects to get the successfulness in speaking English. According to Brown (2000), there are four language skills that must be mastered in learning English including listening, speaking, reading and writing. Between those four skills of language, speaking is one of the most essential components of language, because it is basic function of language as a communication instrument.

The researcher does this study according to previous study by Sunardi, Z and Eni R (2013) entitle "Teaching Speaking Ability through Role Play". The design is using quantitative design. The aim was to know whether role play can increase the students' ability in speaking of tenth grade. In the previous research, there are 
some problems in fluency and pronunciation because they were lacked of vocabulary, hesitation to develop interaction, and intonation and they lack of preparation. Meanwhile, use this techniques can make students more active in expressing their performance, develop their creativity, improve courage and confidence and improve the students' motivation in learning process. So, that way the researcher will do this researcher again because she wants to increase students speaking skill especially in fluency aspect with different steps using Role Play technique.

Based on the statement above, the researcher assumes that applying role play technique is effective toward the students speaking skill because it gives students more chance to practice and gives more opportunities to the students to make turn in speaking during the times allocated. The writer will implement for Junior High School especially for grade VII because in this school when the teacher teach speaking she/he only use LKS as media and do not use other technique, so here writer would like to introduce the technique can use to teach speaking class that is Role Play. Besides it the writer will show that learning English is not difficult as they imagine and writer would like to give new atmosphere in learning by giving interesting activities. The researcher thought that role plays are combination between language and fun. The students can practice and express their idea because they do activities with their friends. The researcher wants to know whether the use of role play is effective or not in teaching speaking. So, the researcher is interested to conduct research to see the effectiveness of using role play technique toward the seven grade fluency students speaking skill at SMP Muhammadiyah 11 Sukodadi.

\section{REVIEW OF RELATED LITERATURE}

Speaking is the most natural way to communicate. It is also used for interacting between two people in daily life, such as: at school, at home or some other places. As Gottlieb quoted Underhilles opinion "speaking generally involves two ways communication with interactive role switching between the speaker, who conveys a message, and the listener, who interprets responds to it" (Gottlieb:2006).

Based on the definitions above, it can be concluded that speaking is the process of sharing information with another person, one's knowledge, interests, opinions or ideas. Besides, speaking also is the way to make someone interest to the information that the speaker wants to share.

There are some aspects in speaking skill, according Haris (1974: 75) says that speaking has some aspects as described below:

- Pronunciation refers to be the person's way of pronouncing words. Brown (2004: 157) also states that pronunciation is the language learner has to know how to pronounce and understand the words that are produced by the speaker.

- Grammar is the study of rules of language in inflection. This idea has the same opinion with Lado (1969: 221) who says that it is a system of units and patterns of language.

- Vocabulary refers to the words used in a language. Phrase, clauses and sentence are built up by vocabulary. Wilkins (1983: 111) also states the same idea that in short, vocabulary is very important because without words we cannot speak at all.

- $\quad$ Fluency refers to the one whose expresses quickly and easily. This is also stated by Ekbatani (2011: 34) that fluent speaker is someone who is able to express oneself readily and effortlessly.

- Comprehension denotes the ability of understanding the speakers' intention and general meaning. Heaton (1991: 35) also says so. It means that if a person can answer or express well and correctly, it shows that he comprehends or understands well.

There are two main methods in assessing oral speech. They are holistic and analytical scoring. The analytical scoring is done by breaking down the objective of the final product into criteria parts and each part is scored independently (Tuan, 2012:1). The procedure of this method involves the separation of the various features of a discourse (Tuan, 2012:1). However, the holistic method uses a single global numerical rating to assess the students' performance (Iwashita and Grove, 2003:26). Each of methods has their own advantages and disadvantages. The holistic method is more practical. It has faster and lower lost over the analytic method but the disadvantage of this method provides less information about the weakness and strength of the students. The major disadvantages of the analytical scoring is it takes a lot of time to rate speaking performance since the teacher is required to make more than one decision for every speaking performance but this method provides more useful diagnostic information about the students speaking ability.

Role play is very important in teaching speaking because it gives students an opportunity to practice communicating in different social contexts and in different social roles. In addition, it also allows students to be creative and to put themselves in another person's place for a while. According to Ladousse (2009:5), role play is an enjoyable activity and does not threaten the students. This activity leads the students to play such a drama. 
The students will play role to be another person in certain situation. Of course when people speak they have to know the setting or where the conversation happens and what situation it is.

According to Brown (2001:174), "role play is a popular pedagogical activity in communicative languageteaching classes". It makes the students free to be someone based on their creativity linguistic input. In line with Brown, Nunan (1989:57) also states that role play activities are important in the teaching of speaking because they give the students an opportunity to practice communicating in the different social contexts and target language.

Role play is similar with simulation, that both of them are playing real situation to make real conversation. They have a little differentiation (Ladousse: 1987). Simulation is more complex than role play activities. Simulation is a broader concept than role play. It is complex lengthy and relatively inflexible events. Role play, on the other hand, can be a quite simple and brief technique to organize. It is also highly flexible, leaving much more scope for the exercise of individual variation, initiative and imagination. And role play also included in simulation as well.

In case of role play activities, according to Byrne (1986), role play can be grouped into two types, (1) scripted Role Play, this type involves interpreting either the textbook dialogue or reading text in the form of speech. The main function of the text after all is to convey the meaning of language items in a memorably way (2) Unscripted Role Play, in contrast to scripted role lay, the situations of unscripted role lay do not depend on textbooks. It is known as a free role play or improvisation. The students themselves have to decide what language to use and how the conversation should develop. In order to do this activity, good preparation from teacher and students is really necessary.

Here are the application of script role play and unscripted role play, scripted role play is a role play which is based on the dialogue. To demonstrate a role play activity based on the dialogue, the procedures given by Doff (1988) is as follows: (1) The teacher guides the role play by writing these prompts. Talk as you write to show what the prompts mean. (2) If necessary, go through the prompts one by one and get students to give sentences or question for each one. (3) Call two students to the front: one play the role as "A" and the other one is " $\mathrm{B}$ ". They should improvise the conversation using the prompts to help them. Point out that the conversation should be similar to the one in the textbook, but not exactly the same; the conversation can be shorter than the presentation dialogue. It should just cover the main points indicated by the prompts.(4) Call out a few other pairs of students in turn and ask them to have other conversation based on the prompts.

Based on these procedures, the writer views that the ways of organizing this dialogue can be carried out into pairs of students who would improvise a conversation in front of class, in turns. The teacher can also ask the students to practice the conversation privately with their partners before they act it out in front of the class.

Unscripted role play is role play which is not depend on textbooks. The example and procedures of unscripted role play which is adopted from Doof (1988) book. To demonstrate a role play activity based on the situation, the procedures as follows: (1) The teacher could prepare the whole class, by discussing what the speakers might say and writing prompt on the board to guide the role play and any key vocabulary. (2) The teacher could divide the class into pairs, and let them discuss together what they may say then let them all try out the role play privately, before calling on one or two pairs to act out in front of the class.

The above procedures do not mean an exact to be used. It is flexible; teacher can create or develop procedures which is appropriate and suitable with his/her own class.

\section{RESEARCH METHOD}

\section{a. Research Design}

Here this study using experimental design, the purpose of experimental research here is to find out the result of speaking ability which implemented by VII grade students using Role Play technique. As stated by Arikunto (2006:3) experimental research is an experiment which tries to find whether there is any effect relation or not. Based on Shadish (2002), Quasi-experimental design happens because the random process of experimental and control group cannot be applied. In this research, researcher use quasi experimental because the school does not allow to use true experiment in SMP Muhammadiyah 11 Sukodadi. It is because the classification of the class in SMP Muhammadiyah 11 Sukodadi had been determine by the school. It means that researcher cannot change the classification of the group. So, researcher does not have access to full control the target and the last time for this study is limited. 
In this study, design chart can be seen in figure below:

\begin{tabular}{|lccc|}
\hline \multicolumn{1}{c}{ Group } & Pre-test & Treatment & Post-test \\
Experimental & $\sqrt{ }$ & $\sqrt{ }$ & $\sqrt{ }$ \\
Control & $\sqrt{ }$ & - & $\sqrt{ }$ \\
\hline
\end{tabular}

\section{Table 3.1 pre-test, post-test quasi experimental design}

Where:

$\sqrt{ }$ : with treatment of using Role Play technique

- : with treatment of using drilling technique

\section{b. Population and Sample}

The population of this research is VII grade students in SMP Muhammadiyah 11 Sukodadi 2019/2020. year which consist of 40 students. Besides, sample is the part of the population that you really want to survey. McmMillan and Schumacher (1984:32), state that the sample is a group of subjects had chosen from the population. The researcher uses population sampling technique because VII grade students only consist of 2 classes and the number of population used as sample, so the researcher takes population sampling technique. For the sample, researcher takes two classes which have same average score, that consist of VII-A (experimental group) who were taught by using Role Play with 20 students and VII-B (control group) who were taught by using Drilling with 20 students.

\section{c. Data Collecting`}

In this study, researcher collects data from speaking test by conducting a test before treatment to experimental group and control group. The first data is pre-test that is given for students SMP Muhammadiyah 11 Sukodadi. It is know the ability in express the expression before the students get the treatments. Then, the researcher gives post-test to know the influence Role Play technique in their speaking ability.

After that, the researcher collets the data from students pre-test and post-test score. Then, the researcher begins to analyze the data of pre-test and post-test by using general linier model and the data post-test by using independent sample t-test in SPSS 16.0 program.

\section{d. Data Analysis}

After collecting the data, the researcher will analyze the data. The researcher analyze the data by using $\mathrm{t}$ test from SPSS program especially by using Independent sample t-test. The t-test for independent sample is carried out to determine whether there is any significant between experimental group and control group.

\section{Discussion}

The data gathered from test were analyzed by SPSS 16.0 with the result shown below:

Table 1

Tests of Normality

\begin{tabular}{|ll|l|l|l|l|l|l|}
\hline & & \multicolumn{4}{l|}{ Kolmogorov-Smirnov $^{\text {a }}$} & \multicolumn{2}{l|}{ Shapiro-Wilk } \\
\cline { 2 - 8 } & group & Statistic & Df & Sig. & Statistic & df & Sig. \\
\hline Score & 1 & .141 & 20 & $.200^{*}$ & .955 & 20 & .451 \\
& 2 & .143 & 20 & $.200^{*}$ & .922 & 20 & .109 \\
\hline
\end{tabular}

a. Lilliefors Significance Correction

*.This is a lower bound of the true significance.

The result of Klomogrov Smirnov Sample test for Equality of Variences showed that the Sig value of score pre-test experiment and control group is 0.200 which means that the data was normal because the sig. was higher than the level of the significance $0.200>0.05$, it means that the result of pre-test from two populations of experimental and control group were normal. So, it could be stated that to analyzed the independence variable (Role Play) in teaching speaking. 
Secondly, the researcher analyzed the Homogenity Test of variance by using Levene'. The mean pre-test score of experiment group was 41.7333 and the control group was 40.5333 . The result of independent sample t-test is showed in the following:

Table 2 Test of Homogenity Group Statistics

\begin{tabular}{|ll|r|l|r|r|}
\hline & group & $\mathrm{N}$ & Mean & $\begin{array}{c}\text { Std. } \\
\text { Deviation }\end{array}$ & Std. Error Mean \\
\hline score & 1 & 20 & 41.7333 & 5.74059 & 1.28364 \\
& 2 & 20 & 40.5333 & 4.50393 & 1.00711 \\
\hline
\end{tabular}

Independent Samples Test

\begin{tabular}{|c|c|c|c|c|c|c|c|c|c|c|}
\hline & & $\begin{array}{l}\text { Leven } \\
\text { for Equ } \\
\text { Vari }\end{array}$ & $\begin{array}{l}\text { s Test } \\
\text { lity of } \\
\text { nces }\end{array}$ & \multicolumn{7}{|c|}{ t-test for Equality of Means } \\
\hline & & \multirow[b]{2}{*}{$\mathrm{F}$} & \multirow[b]{2}{*}{ Sig. } & \multirow[b]{2}{*}{$\mathrm{T}$} & \multirow[b]{2}{*}{ Df } & \multirow{2}{*}{$\begin{array}{l}\text { Sig. (2- } \\
\text { tailed) }\end{array}$} & \multirow{2}{*}{$\begin{array}{c}\text { Mean } \\
\text { Difference }\end{array}$} & \multirow{2}{*}{$\begin{array}{c}\text { Std. Error } \\
\text { Difference }\end{array}$} & \multicolumn{2}{|c|}{$\begin{array}{c}95 \% \text { Confidence } \\
\text { Interval of the } \\
\text { Difference }\end{array}$} \\
\hline & & & & & & & & & Lower & Upper \\
\hline score & $\begin{array}{l}\text { Equal } \\
\text { variances } \\
\text { assumed } \\
\text { Equal } \\
\text { variances } \\
\text { not } \\
\text { assumed }\end{array}$ & .116 & .121 & $\begin{array}{l}.735 \\
.735\end{array}$ & 38 & .467 & 1.20000 & 1.63156 & -2.10292 & $\begin{array}{r}4.502 \\
92 \\
\\
4.509 \\
07\end{array}$ \\
\hline
\end{tabular}

The result of Levene's Test for Equality of Variances showed that the $\mathrm{F}=0.116$ and the sig. $=0.121$ of score pre-test between control and experiment group which means that there was no different variance between experimental group and control group because the sig. value of score pre-test experiment and control group was higher than the level of the significance $0.121>0.05$. It means that two population of variance were homogeneous or equal.

Table 3 Test of Hypothesis Group Statistics

\begin{tabular}{|c|c|c|c|c|c|}
\hline & group & $\mathrm{N}$ & Mean & Std. Deviation & Std. Error Mean \\
\hline \multirow[t]{2}{*}{ Nilai } & 1 & 20 & 57.8667 & 6.18468 & 1.38294 \\
\hline & 2 & 20 & 53.9000 & 6.01470 & 1.34493 \\
\hline
\end{tabular}




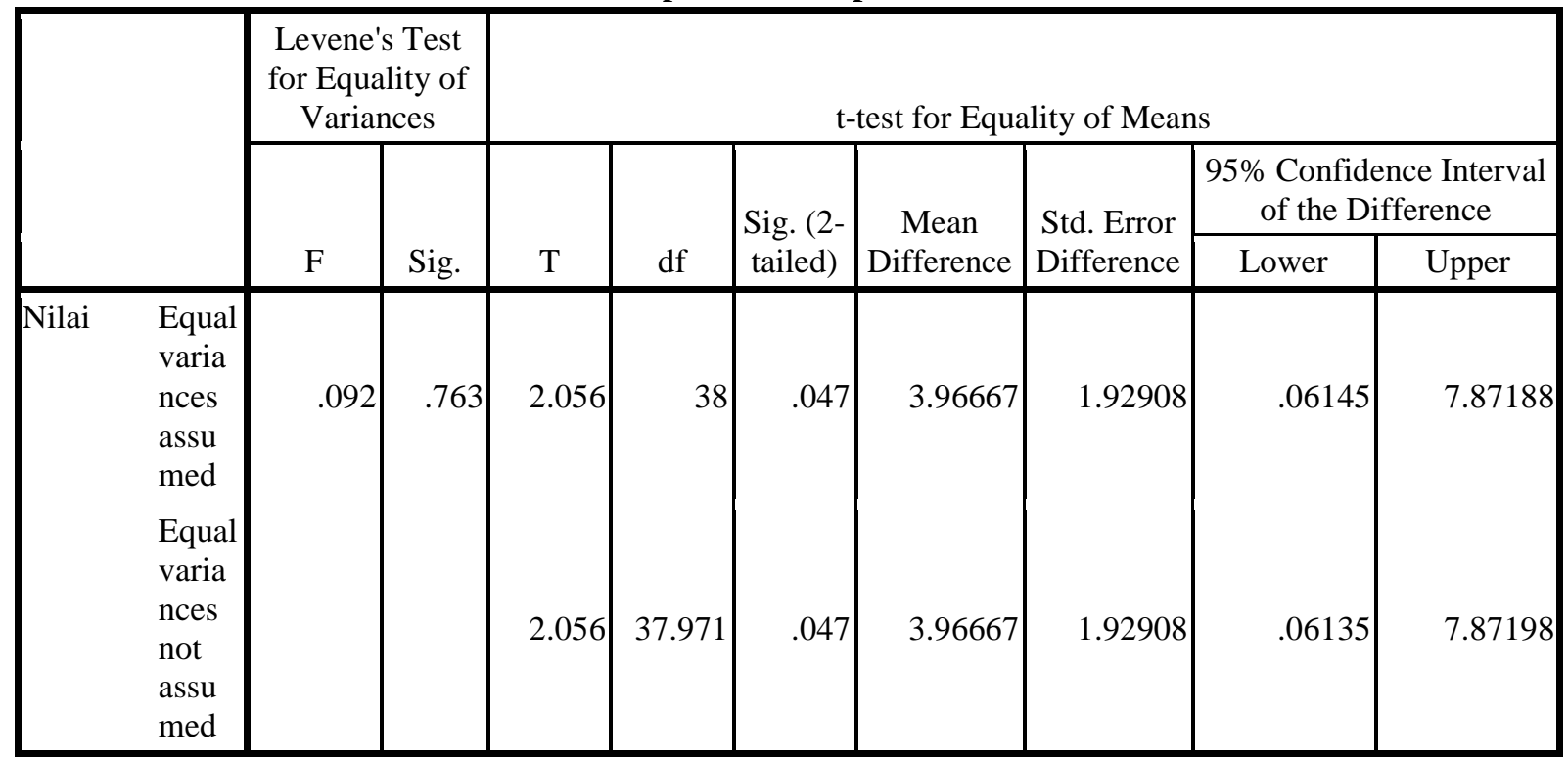

The result of mean experimental was 57.8667 and control group was 53.9000. It showed that the mean was gained by the experimental class which was higher than control class. It was indicated that the treatment was working. However, to see the significant of the mean difference, Independent t-Test computation was conducted. T-test was calculated to find out the comparison of two means between experimental group and control group. The table above showed that the value of Sig. (2tailed) was 0.47 in critical value for $5 \%$ level. It is mean that the significant value was less than $5 \%$ or $(0.05>0.047)$. So, the null hypothesis could be rejected. It can be concluded that there is enough evidence to conclude that the use of Role Play better than Drilling to improve speaking ability at VII grade of SMP Muhammadiyah 11 Sukodadi.

Based on the explanation above, the researcher found that there was significant difference in speaking ability between the students who were taught using Role Play and who were taught by Drilling. It was indicated that Role Play significantly influenced in speaking ability for VII grade at SMP Muhammadiyah 11 Sukodadi.

\section{CONCLUSION}

The result of this study was used Role Play can develop their critical thinking, organizing materials, and increase students motivation. It can be considered as an effective strategy for improving students speaking ability performance as it involves students in learning process. Besides, the students can improve their fluency and creativity in speaking skill. Students not only become more interested in their learning but also take more responsibility for their learning. In this research, the researcher used Role Play without scripts so, here students can develop the students imagine and increase the self-confidence with speak fluency. They can be motivated and their oral abilities and competence can be developed. Beside it, used Role Play not only improves speaking skill but also improve the other skills such as reading, listening and writing.

Then, the researcher analyzed the hypothesis testing and the result showed that the value of Sig. (2tailed) was 0.047 in critical value for $5 \%$ level. It is mean that the significant value was less than $5 \%$ or $(0.05>0.47)$. So, the null hypothesis could be rejected. It can be conclude that there is enough evident to conclude that the use of role play better than drilling to improve speaking ability at VII grade of SMP MUHAMMADIYA 11 SUKODADI especially in fluency.

\section{REFERENCES}

Anai, Padang Pariaman Regency, West Sumatra, Indonesia). The Journal of Applied Sciences Research., 279283. 
Brown, H. D. (2000). Principles of Language Learning and Teaching. 4th ed. New York : Addison Wesley Longman, Inc.

Brown, H. D. (2001). Teaching by Principles: an Interactive Approach to Language Pedagogy. New York: Addison Wesley Longman Inc.

Budiman, A. (2004). Role Play to Enhance Students' Speaking Ability, Skripsi. Tangerang: UIN Syarif Hidayatullah Jakarta.

Buzanni. (2008). The Use of Guessing Games in Improving Students' Speaking Ability at the Second Year Students Of MTS Ikhtiyarul Ummah Pamekasan.

Byne, D. (1986). Teaching Speaking Oral English: Longman Handbooks for English Teacher. p. 122-123 page 25.

Cameron, L. (2001). Teaching Language to Young Learners. Cambridge: Cambridge University Press.

Celce-Murcia, M. (2001). Teaching English As A Second or Foreign Language. Boston: Heinly and Heinle, a Division of Thomson Learning,Inc.2001, 106-108.

Doff, A. (1988.). Teach English: A Training Course for Teachers trainer's Handbooks. In The British Council. (pp. 233-234). Cambridge.: Cambridge University Press Inc.

Gottlieb, M. (2006). Assessing English Language Learners. California: Corwin.

Harmer, J. (2001). The Practice of English Language Teaching. Cambridge: Pearson Education Limited.

Harmer, J. (2007). How to Teach English. London: Longman.

Harmer, J. (2007). The practice of language teaching. fourth edition. Edinburg: Pearson Education Limited.

Huang, I. (February 2008). Role Play for ESL/EFL Children in the English Classroom. TESL Journal., Vol.XIV, No. 2.

Iwashita, N. E. (2003). "A comparison of Analytical and Holistic Scale in the Context of a Specific-purpose Speaking Test". The Prospect Journal, Vol. 18, No. 3 December 2003.

Ladousse, G. P. (1987). Role Play. Oxford: Oxford University Press.

Ladousse, G. (2009). Role Play. New York: Oxford University Press.

Nasional., D. P. (2009.). Model Pembelajaran yang Efektif. Jakarta.: Depdiknas.

Nunan, D. (1989). Designing Tasks for the Communicative Classroom. Cambridge: Cambridge University Press.

Nunan, D. (2003). Practical English Language Teaching. NY: McGraw-Hill.

Olshtain, E. a. (2001). Teaching Speech Act Behavior to Nonnative Speakers. Boston: Heinle \& Heinle Publisher.

Richard, J. C. (2002). Methodology in Language Teaching. Cambridge: University Press.

Richards, J. C. (1986). 2nd Edition Approaches and Methods in Language Teaching. New York: Cambridge University Press.

Richards, J. C. (2006 ). Communicative Language Teaching Today. New York: Cambridge University Press.

Sari, N. P. (2006). Improving Students' Speaking Ability by Using Role Play, Skripsi. Tangerang: UIN Syarif Hidayatullah Jakarta.

Sunardi, Z. A., \& ROsnija, E. (2013). TEACHING SPEAKING ABILITY THROUGH ROLE PLAY.

Thombury, S. (2007). How to Teach Speaking. London: Longman Press.

Tuan, L. (2012). "Teaching and Assessing Speaking Performance through Analytic Scoring Approch". Theory and Practice in Language Studies, Vol. 2, NO. 4, PP. 673-679, aPRIL 2012, 673-679.

Ur, P. (1996). A Course in Language Teaching. Cambridge: Cambridge University Press.

Yuliana Y, K., \& Suhartie. (2014). The Effect of Role Play Toward Students' Speaking Skill (an Experiment Study at Grade XI IPA High School 1 Batang. 